\title{
EUROPEAN PATH OF THE WESTERN BALKANS REGION - NORMATIVE ASPECTS AND GEOPOLITICAL FACTORS
}

The purpose of the study is to analyze the general and regional context of the process of accession of the Western Balkans region to the European Union (EU). The Union (EU) is in a negative stage of its development, especially following Brexit, and even more since the pandemic has seriously shaken complete global economy and the economy of the EU as well. Those unfavourable factors added a bad momentum to the on-going monetary crisis that started in 2008. Therefore, the general context of the EU enlargement process is to be taken into consideration when analyzing the accession of each candidate country from the Western Balkans region. The next relevant context is the regional one. The dynamics of the accession process of these countries to the Union remains open. The EU is at the turning point in its evolution in contemporary conditions. Consequently, many authors are posing the question of the future of the EU. The enlargement process is not a priority for the Union, bearing in mind its internal problems, institutional, and even more, economic problems, especially after the outbreak of the pandemic. After The EU - Western Balkans Zagreb Summit of May 2020, this became evident.

It remains to be seen in the upcoming period whether "Europe-Fortress" is on the scene, with semi-open doors to candidate countries from the Western Balkans region, or is it Europe without borders. Membership in the EU can be one, but not the only alternative to those countries that are committed to improving their relations with the Union.

Keywords: EU, enlargement, Western Balkans, crisis

\section{INTRODUCTION}

The European Union (EU) is in a negative phase of its development, especially after the recent Brexit and the outbreak of corona virus pandemic, which added a bad momentum

${ }^{*}$ Gordana Gasmi, PhD, Research Fellow, Institute of Comparative Law. Email: g.gasmi@iup.rs

** Dragan Prlja, PhD, Research Fellow, Institute of Comparative Law. Email: d.prlja@iup.rs 
to the current monetary crisis, which began in 2008. Therefore, the general context of the EU enlargement process, namely the internal crisis within the Union should be taken into account when analyzing the accession of each candidate country from the Western Balkans region. Another relevant context is the regional framework for the accession of the Balkan countries.

Despite the prolonged crisis, the Union has not completely given up expanding its membership, but there is certain development fatigue, "Fatigue de l'Europe", given the EU's numerous institutional, political and economic problems. It follows that the enlargement process is no longer a priority issue for the $\mathrm{EU}$, which should primarily build its security and defense identity in the recurrent culmination of the migrant crisis (Gasmi\&Zečević, 2016, p. 58). In addition, there has been a fall in EU membership since the departure of Britain (Gasmi, 2016, p. 235). All these geopolitical factors make bad news for the candidate countries from the Western Balkans region.

The good news is that at the EU-Western Balkans Summit in Thessaloniki in June 2003, the Union promised a strategic partnership with the Western Balkan countries in their accession to the EU and their secure European future, but without a precise timetable.

Due to the slow pace of the enlargement process, despite the formal progress of these countries towards accession, during the Bulgarian Presidency of the Council of Ministers, an EU-Western Balkans summit was held fifteen years later (May 2018, Sofia), under the striking title: „In the Western Balkans: Creating a region of growth, security and connectivity on the road to Europe. "The aim of this Summit was to give a fresh impetus to the integration of the Balkan countries into the Union by 2025 . The prospect of possible future membership by 2025 represented a new opportunity for the region to complete all necessary internal reforms. Bulgaria has included in its program of the EU Council Presidency a strategic focus on connecting the Western Balkan countries with the Union, at all levels. The leading vision was of the EU as the best geo-strategic choice for the Western Balkans (Matias, 2018).

Meanwhile, in 2014, Germany launched the Berlin Process as an intergovernmental platform for cooperation with the Western Balkan countries. As part of this process, in the years 2014-2018, annual summits were held, attended by EU representatives and heads of state and government of the Western Balkan countries. However, the question of the timing of those countries' accession to the Union remained open.

Therefore, it is necessary to pose the essential question of the context of the contemporary process of accession of the Western Balkans countries to the Union, in order to provide an answer about the prospects of this process, especially given the pandemic, which is a global socio-economic cataclysm.

\section{GENERAL CONTEXT OF THE EU ENLARGEMENT - UNION'S BLACK MOMENTUM}

Seen through the prism of recent history, the EU suffered a huge influx of refugees during the tumultuous 2015, as well as, in the previous period, a debt crisis in Greece and two waves of terrorist attacks in Paris. Of all these, during the previous period, the most 
devastating was the migrant crisis, which pointed to the EU institutional problems and the absence of a common Union migration policy.

Even then, there was talk of repealing the Schengen Agreement, which legally symbolized a borderless space among Member States, in the situation of raising concrete and wire barriers at border crossings between those same states and in the midst of their mutual accusation of a lack of solidarity in the care of refugees. The situation was all the more aggravated given the negative security dimension of the migrant crisis, because without the transparent registration of refugees, no one can guarantee that there are no well-trained terrorists among the migrants. The magnitude of migrants' attacks in Germany (Cologne), Finland and Austria are proof.

On the other hand, this situation has served to strengthen national extreme-right movements and Eurosceptics within the EU Member States, and has become even more an indicator of the Union's institutional weaknesses. The Schengen Agreement (1985) is a legal reflection of the idea of free movement of people, but also a reflection of the fears of immigration and cross-border organized crime. It was signed by the Benelux countries (the Netherlands, Belgium and Luxembourg), the Federal Republic of Germany and France, which are the five founding members of the Community.Other countries signatories joined gradually. The Schengen agreement originally provided for a gradual suspension of controls at the internal, common borders of these countries (Lopandić\&Janjević, 1996, p. 225). The Schengen Agreement was followed by the Convention on its Implementation (1990), which entered into force in 1995. Those legal documents constitute the Schengen Acquis, which since the adoption of the EU Treaty of Amsterdam (1999), has become an integral part of the Acquis Communautaire.

Many regulations under the Schengen Acquis are recommendations i.e. the so-called soft law on the EU standards on migration policy, the right of entry, stay and return of foreigners, as well as the issues of preventing illegal migration, combating human trafficking and protection of personal data. All these types of recommendation are addressed to the Member States with a view to creating and implementing a common migration policy. It should be noted that the Schengen Acquis gradually expanded, although it has never extended to all Member States. Namely, the UK and Ireland remained outside, as did the new members who had to pass a period of compliance with the Schengen criteria (Romania, Bulgaria and more recently Croatia). Cyprus is outside Schengen due to the unresolved issue of Turkey's occupation of the northern part of the island. Non-EU countries are also signatories to Schengen (Norway and Iceland, 2001), followed by Switzerland (2008), as well as Liechtenstein (Piris, 2010, p. 192,193).

The Convention Implementing the Schengen Agreement established an Executive Committee with the task of normatively regulating the application of the provisions of the Schengen Agreement and monitoring their implementation. The Convention also regulates in more details the abolition of control at the internal borders of the Schengen members and the conditions of entry of foreigners, ie. all non-EU nationals. Exempli causa, specific consequences for third-country nationals, ie. those non-Schengen countries, include that the refusal of a visa by one Schengen Member State automatically means that the foreigner does not have the possibility of obtaining a visa in the other Schengen area. The Maastricht 
Treaty (1993) in the provisions of Art. 100c introduces common visa lists and a uniform visa format in the EU Member States.

In this way, issues related to the visa regime (the list of third countries whose nationals are obliged to require visas) have been transferred to the competence of the EU bodies, ie the first pillar of supranational decision-making. This is not the case with the other issues of cooperation between the EU Member States in the area of justice and home affairs, which formed the former third pillar (Ivanda, 2001, p. 17), before the EU Treaty of Lisbon and the merger of all three pillars into one whole legal personality of the EU. This area is characterized by intergovernmental cooperation between the Member States, ie coordination of the Member States' national policies and unanimous decision-making.

Following the Treaty of Lisbon, the Council of Ministers is still responsible for determining the so-called white and black lists of the visa regime. One such example is Council Regulation no. 539 of $2001^{81}$. The complexity of Member States' cooperation in the areas of security, justice and home affairs, in addition to the existence of different national interests, was further exacerbated by the migrant crisis. The abolition of Schengen at the end of 2015 happened in a de facto manner, which is non-institutional and without a formal decision at the level of the Union bodies. Despite efforts to build the Union's security and foreign policy identity, reality has denied this endeavor.

Hungary is geographically the first country to be hit by the EU asylum procedure, which under the Dublin Convention provides that the first country where asylum seekers apply should implement the procedure for registering asylum seekers and considering the reasons for seeking asylum. Majority of migrants have refused registration, which has led to clashes with the Hungarian police and heightened tensions within the Union, following the ban on their further movement to other EU Member States. Hence, Italy, through its Foreign Minister, Paolo Gentiloni, emphasized the need for the adoption of unique EU asylum regulations. Specifically, it was noted that the asylum application system in the first Member State where the migrants were found was no longer viable, as exemplified by Hungary. On the other hand, it is necessary to respect the values of the EU that protect human rights and democracy, and to ensure that refugees in the spirit of the UN Geneva Convention (1951), who flee war or dark dictatorial regimes, are protected and separated from economic migrants. Italy and Germany have pointed out that dealing with asylum issues at the national level of the Member States dramatically threatens Schengen functioning and freedom of movement within the EU (Gasmi\&Zečević, 2016, p. 68).

Some authors (Macek, 2015, p.3) even question whether there was a new East-West division within the EU, given the opposition of the former Visegrad Group (1991), Hungary, the Czech Republic, Slovakia and Romania to establishing a voluntary distribution of migrants through the EU quota system. Poland endorsed, at the last minute, the majority position of the Member States at the September meeting of the Council of Ministers (2015). It can be assessed that this is not a new East-West division within the EU, although there is a lack of unity among the EU members.

${ }^{81}$ Council regulation (EC) No 539/2001 of 15 March 2001 listing the third countries whose nationals must be in possession of visas when crossing the external borders and those whose nationals are exempt from that requirement", Official Journal of EC, L 81, 21 March 2001, pp. 1-7. 
The countries of the former Eastern Bloc were not colonial powers and have no tradition of accepting immigrant populations into their societies. Furthermore, democratic traditions differentiate in relation to Western Member States, as well as understanding of the concepts of the Union values, the degree of political culture and the perception of the identity of the EU and its place in the world. The dose of fear and rejection of refugees coming from outside Europe can be explained by the ignorance and considerable level of closure of Eastern European societies due to their former affiliation with the Eastern Bloc. If these cultural and geopolitical factors are added to the economic problems in these countries, where labor markets are not as attractive as in the West of the Union, the situation becomes easily explained. For example, the minimum wage per hour in Bulgaria and Romania is about one euro, while in Germany it is more than eight euros, starting from 2015 (Schulten, 2014, p. 4).

In this context, it is important to note that on April 2, 2020, the European Court of Justice ruled that three EU countries: the Czech Republic, Hungary and Poland violated $\mathrm{EU}$ regulations when they refused to receive migrants under the EU's temporary quota system of 2015. The Court said that in refusing to comply, the three Member States had no right to cite "maintaining law" or 'safeguarding internal security', or claiming that the relocation program was "dysfunctional" ${ }^{2}$. At the time of writing this paper, it is up to the EU Commission if it wants to follow the Court ruling. The Commission could determine that the original 2015 Council Decision ${ }^{83}$ could still be implemented and launch a second infringement procedure for financial penalties. All of those Commission considerations would be subject to scrutiny by the Court.

The above facts illustrate the serious absence of economic and political cohesion within the Union.

Another major highlight in the culmination of years of the EU agony is Britain's withdrawal from the EU membership, as a result of a national referendum held in June 2016 with a negative answer to the question of remaining a member of the EU. At the time of writing this paper, the complete consequences of the UK leaving the EU membership are not completely perceived. On 23 June 2016, the UK organized a referendum on leaving the EU (BREXIT - Britain exit). According to the final results of the UK exit referendum, 51.9 percent voted to leave the country and 48.11 percent to remain in the Union ${ }^{84}$. Voting analysis shows that, for the most part, residents in smaller UK cities opted to exit the Union. It happened after forty-three (43) years of the UK membership.

It is a serious blow to the further institutional and economic development of the Union, the consequences of which will be felt for a long time. It can be assessed that

82 ECJ Judgment in Joined Cases C-715/17, C-718/17 and C-719/17 Commission v Poland, Hungary and the Czech Republic, Court of Justice of the European Union PRESS RELEASE No 40/20 Luxembourg, 2 April 2020, www.curia.europa.eu.

${ }^{83}$ Council Decision (EU) 2015/1601 of 22 September 2015 establishing provisional measures in the area of international protection for the benefit of Italy and Greece (OJ 2015 L 248, p. 80). The validity of that decision was the subject-matter of Joined Cases C-643/15 and C-647/15, Slovakia and Hungary v Council, Press release No 91/17, www.curia,europa.eu.

${ }^{84}$ Based on the counted votes in all 382 local election centers, 17,410,742 citizens voted in favor and 16,141,241 voters remain. http://www.blic.rs/vesti/politika, June 24, 2016. 
the Union is indeed at the turning point of its functioning. The UK's stay in the EU was also not helped by the fact that on 19th February 2016, the European Council decided to grant special status to Britain in case it voted to remain in the Union (Deloy, 2016, p. 2). This meant that $55 \%$ of national parliaments would be able in the future to use a "red card" to block a draft EU directive. In addition, with regard to social benefits for European immigrants, access to certain types of social benefits will be blocked indefinitely if "public services are exhausted".

The British referendum was nevertheless won by Euro-skeptics ${ }^{85}$, who saw the main threat to the sovereignty of Great Britain in the current threatening migrant crisis, but even more so in the decisions of the Brussels administration, which they characterized as threatening the country's economic growth. Immediately after the referendum, the resignation of British Commissioner Lord Hill, a member of the EU Commission responsible for financial services and the capital market, followed. Former President Jean-Claude Juncker regretfully accepted the resignation and nominated Vice-President of the Commission V. Dombrovskis, otherwise in charge of the euro and social dialogue ${ }^{86}$, by publishing a special Commission declaration on the EU's official portal. Particularly warning is the fact that the resignation took place immediately after the British referendum (BREXIT), despite the fact that the Commissioners are elected in a personal capacity on the basis of general competences and given their European engagement, which guarantees their independence from national governments ${ }^{87}$.

The EU representatives' response to the BREXIT result came in the form of the Declaration of Foreign Ministers of the founding countries of the European Communities. The MFAs of France, Germany, Italy, Luxembourg, the Netherlands and Belgium met on June 25th, 2016, and expressed regret concening the decision of the British people to leave the Union. The Declaration estimates that there has been an upheaval for the EU, which has lost its Member State, thereby ending the proposal of the UK's special status, which was voted on at the February European Council meeting. Bearing in mind that the provisions of Art. 50 of the Lisbon Treaty foresees voluntary exit from the EU, ministers had called on the UK to activate the envisaged mechanisms for opening negotiations on the withdrawal Agreement ${ }^{88}$. This Agreement was finally reached at the end of January 2020, after cumbersome negotiations between the EU representatives and the UK Government and after breaking a two-year deadline for defining it.

Some authors have argued that after the UK exit, the so-called domino effect cannot be ruled out, bearing in mind that the Netherlands, due to some discontent with the expansion of EU membership. Specifically, on April 6th 2016, the Netherlands rejected the EU - Ukraine Accession Agreement with $61 \%$ of the negative votes in the referendum. The same effect evolved in France, where after the British referendum, a public debate

\footnotetext{
${ }^{85}$ http://www.electoralcommission.org.uk, 24th June 2016.

${ }^{86} \mathrm{http} / / /$ europa.eu/rapid/press-release_STATEMENT-16-2332_fr.htm, 25.June 2016.

${ }^{87}$ Art. 17, par. 3 of the Lisbon Treaty, Annex I.

${ }^{88} \mathrm{http} / / /$ www.diplomatie.gouv.fr/fr/politique-etrangere-de-la-france/europe/evenements-et-actualites-liesa-la-politique-europeenne-de-la-france/article/declaration-conjointe, 25, Juin 2016.
} 
flared upon the so-called Frexit, which is the possibility of France leaving the EU(Chopin \&Jamet, 2016, p. 5).

The United Kingdom has, over more than four decades of its membership, been permanently with one foot out of the EU, by the very fact that during the establishing of the EU it managed to get the so-called opt-out clause, i.e. a waiver of joining the monetary union and adopting a single currency. The second exception was rejecting the Social Protocol on Workers' Rights, when adopting the Maastricht Treaty (1993). In this context, it is also important to point out Britain's formal absence from the Schengen system of common visa lists and the area of freedom of movement and residence for EU citizens. (Gasmi, 2016, p. 238, 239). It follows that these are very serious exceptions to the membership obligations, which led to the final compromise proposal on the UK's special status in the event of her stay in the Union, adopted in February 2016 at the European Council. Nevertheless, the concept of maintaining the UK's strong national political and economic sovereignty prevailed.

The situation of the non-institutional abolition of the Schengen Agreement recurred during the March 2020 pandemic. Then again, the non-institutional termination of the Schengen Agreement happened due to the implementation of national preventive measures to restrict movement in order to combat the pandemic. On the one hand, one cannot dispute the justification of restrictions on the free movement of persons for the protection of public health, but on the other hand, it was worrying that there had been no previous decision at the level of the EU institutions. Each Member State introduced, at their own discretion and in different time intervals, preventive measures to combat the pandemic. The Commission subsequently presented the "COVID-19 Guidelines on Border Measures to Protect Health and Ensure the Availability of Essential Goods and Services" ${ }^{89}$, which legitimized national closures of internal borders by Member States after they took place.

The absence of solidarity of other EU members towards Italy, France and Spain, the Member States that have suffered the most losses of lives due to the pandemic, indicated a breakdown in European values, which are legally protected and proclaimed in the Lisbon Treaty (Art. 2). Normatively seen, these provisions of the Treaty of Lisbon place emphasis on universal values, such as: human dignity, freedom, democracy, equality, the rule of law and respect for human and minority rights." These values are common to the Member States in a society in which pluralism, non-discrimination, tolerance, justice, solidarity and equality between women and men prevail." Therefore, some authors point out that the Lisbon Treaty (TEU) is deeply rooted in human rights, since those provisions of Art 2 regarding the Union's values have not only political, but also concrete legal effects (Piris, 2010, p. 71). Lisbon Treaty gave to the EU Charter of Fundamental Rights the same legal value as the Treaties by virtue of Art 6 (1) TEU. Furthermore, in par. 2 of Art.6 stipulates the obligation of the Union to accede to the European Convention for the Protection of Human Rights and Fundamental Freedoms.

89 "As regards measures linked to border management, coordination at EU level is key.Therefore, these guidelines set out principles for an integrated approach to an effective border management to protect health while preserving the integrity of the Single Market." Brussels, 16.3.2020, C(2020) 1753 final. 
As being the case during the peak of the migrant crisis in 2015/2016, solidarity among the Member States has vanished again during the pandemic. The normative concept of solidarity is defined in Solidarity clause (Art. 222 of TEU), which sets forth a joint action of the Member States in a spirit of solidarity if a Member State is the object of a terrorist atck or a victim of a natural or man-made disaster. Joint action assumes mobilisation by the Union of all instruments at its disposal (Gasmi G, 2016: 88). The arrangements for the implementation by the Union of the solidarity clause shall be defined by a decision adopted by the Council of Ministers. The European Parliament shall be informed. Furthermore, the European Council shall regularly assess the threats facing the Unionin order to enable the Union and its Member States to take effective action. However, this normative framework of solidarity was denied by reality of events during pandemic. Consequently, some authors (Brehon N. J. 2020) have assessed that the coronavirus has shown the fragility of the EU societies and their flawed solidarity.

Some EU countries have forbidden the export of necessary medical equipment during the pandemc even to other Member States of the Union, which proved to be disastrous especially to Italy and Spain that counted one thousand deaths a day and also to France and Belgium with their significant outbreak of the pandemic. Angela Merkel, the Chancellor of the Federal Republic of Germany, has warned in her speech of 6th of April 2020 that the EU is faced with the greatest challenge in its history ${ }^{90}$, while other pro-Europeans accused the European Commission of a lack of action in issuing measures to manage this health crisis and its economic consequences. The pandemic affected all countries, but it hit especially hard in the countries of the EU South, which have already suffered most during the migrant crisis $^{91}$. The president of the European Commission, Ursula von der Leyen, announced on Thursday ( 2 April) "a new solidarity instrument" of $€ 100 \mathrm{bn}$ in financial assistance, in the form of loans, to support workers affected by the coronavirus outbreak. This unemployment reinsurance mechanism named SURE would require Member States to provide guarantees collectively, amounting to at least $€ 25 \mathrm{bn}$ based "on a voluntary basis" 92 . Furthermore, regardless of whether it is called Coronabonds, Recoverybonds, Sanitarybonds, an exceptional investment plan, what the Union needed was a major act which was to express voluntarily its solidarity in the face of the pandemic. However, the deal on that issue was not reached. Instead, EU ministers of finance agreed on a financial aid package of billion euros. Therefore, some authors qualified the dramatic situation as "then or never" (Giuliani, 2020).

The EU, legally seen, has limited powers to tackle the pandemic - healthcare is in the national competence of the Member States. The European Commission is authorized to coordinate and support the Member States on health. It can make recommendations and give advice, but the Member States are free to ignore it. This is the exact reason why the pandemic proved to be a watershed moment for the EU solidarity. Finally, the negative momentum of the EU was underlined by the fact that a coordinated action of the EU

\footnotetext{
${ }^{90} \mathrm{https} / / /$ euobserver.com/coronavirus/148003?utm_source=euobs\&utm_medium=email.

${ }^{91}$ https://euobserver.com/opinion/147954?utm_source=euobs\&utm_medium=email.

${ }^{92} \mathrm{https} / / /$ euobserver.com/coronavirus/147976?utm_source=euobs\&utm_medium=email.
} 
Commission in combating the pandemic was very late, while chaos reigned in the market of necessary medical equipment. Therefore, it turned out that during the pandemic, the EU single market has totally totally given way to the national protectionist economic measures of the Member States.

Geopolitical factors that have occurred during the pandemic, indicated that the USA has underestimated the pandemic, and its central administration has proved that it no longer holds the necessary political and moral authority to effectively coordinate the battle against the global coronavirus. Therefore, the EU, in the context of multilateral cooperation, was expected to step in and pave the road for the management of the unprecedented health crisis and its social and economic consequences, and to link Europe's core values to the technical and political capacity in an innovative way offering the world a message of hope and strength against the pandemic. However, it did not happen.

EU High Representative for foreign policy, J. Borrell criticised Russia and China for their humanitarian aid during the pandemic, which had been used for spreading geopolitical influence in Europe ${ }^{93}$. China has clearly taken advantage of the geopolitics of money as it takes part of the Silk Roads through the region, lending considerable sums of money to the Balkan States or acquiring many companies in strategic sectors (energy, transport, etc.), thereby making these countries highly dependent on this new Chinese diplomacy. It was clear that China achieved success in this global geopolitical game.

\section{SPECIFIC CHARACTERISTICS OF THE WESTERN BALKANS IN THE EU ACCESSION - A VIEW FROM THE REGION}

The countries of the Western Balkans (WB) do not have a common strategy aimed at improving and accelerating their accession to the EU. Hence, the regional context can only be described conditionally, from the standpoint of the specific characteristics of the region itself. The term Western Balkans refers to the grouping of countries, which the Union has introduced under the political designation of the region and includes Bosnia and Herzegovina, Albania, North Macedonia, Serbia and Montenegro. These countries view the normatively defined criteria for enlargement of the EU membership, in the Lisbon Treaty on the EU (Art. 49), above all as a political criterion, being a barrier that the EU has set for these countries.

The primary feature is that the region lacks homogeneity in economic and political terms. Partly due to the EU approach, there ia a stratification of each country's political status into the so-called "in" countries (candidate countries) and on the other hand "out" ie. non-candidate countries. Of course, this complex stratification also has some legal, but even more geopolitical and economic consequences for the homogeneity of the region.

\footnotetext{
93 "There is a geo-political component including a struggle for influence through spinning and the 'politics of generosity. Overall, the task for the EU is to defy the critics and demonstrate in very concrete terms that it is effective and responsible in times of crisis."Borrell, https:/eeas.europa.eu/delegations/china/76401/eu-hrvpjosep-borrell-coronavirus-pandemic-and-new-world-it-creating_en, accessed in April 2020.
} 
When these facts are added to the prevailing unfavorable geopolitical image of the region within the $\mathrm{EU}^{94}$, seen as a post-conflict area with strong security challenges $-\mathrm{a}$ "powder keg", due to insufficiently resolved neighborhood relations in the region, the need for a common strategy in the EU accession by different countries in the region is obvious. This phenomenon is a huge challenge in the accession process, especially given the complex problem of Kosovo.

The example of Serbia in the process of the EU accession shows insufficient support from the region, especially from the former EU candidate - Croatia, who became a fullfledged EU member in July 2013. In this context, the question arises of the expediency of the EU conditionality policy, proclaimed at the Thessaloniki Summit, with the idea of evaluating the economic, legal and political reforms achieved in the candidate countries. Since joining the EU, Croatia has found itself in a position that allows it to use the EU accession process as a means of pressure in its bilateral relations with Serbia. The situations of denial of Croatia's agreement to open the EU negotiations with Serbia on individual chapters persist (eg Chapter Twenty-six on Culture and Education, in 2018).

Hence, the regional context of these problems is also very significant. Thus, in the absence of regional solidarity of the candidate countries in the region, many deviations occur in the process of their EU accession. An example of this is the decline in support for European integration in some Western Balkans countries due to a non-coherent official EU approach.

In addition, there is an insufficient degree of developed regional cooperation among the countries of the region, as a direct manifestation of a commitment to European integration. More precisely, the Union (Fouéré, 2015, p. 2) advises the candidate countries not to ask each other what they are not prepared to offer in terms of economic cooperation, reconciliation processes and political stability.

After the initial recovery, the region entered a phase of recession and stagnation, especially after 2008, when a monetary crisis erupted, reflecting the region's further backwardness, high unemployment, corruption and organized crime, as well as the deteriorating political climate in the region. There are certainly exceptions from this bleak picture, due to Serbia's successful economic recovery from 2014 to 2019. The unfavorable situation of the region was exacerbated by the pandemic in early 2020 with devastating consequences for the public health and economies of the countries in the region as well as globally. The International Labor Organization estimates that about 200 million jobs will be lost as a result of the pandemic, globally seen ${ }^{95}$. At the time of writing the present paper, the tentative estimates of global socio-economic damages resulting from the pandemic are contained in the UN report: "Global growth in 2019 was already the slowest since the global financial crisis of

\footnotetext{
${ }^{94} \mathrm{EU}$ member states and enlargement towards the Balkans, July 2015, European Policy Centre http://aei.pitt. edu/66050/1/pub_5832_eu_member_states_and_enlargement_towards_the_balkans.pdf.

${ }^{95}$ Workers in four sectors that have experienced the most "drastic" effects of the disease and falling production are: food and accommodation (144 million workers), retail and wholesale (482 million); business services and administration (157 million); and manufacturing (463 million). Together, they add up to 37.5 per cent of global employment and this is where the "sharp end" of the impact of the pandemic is being felt. https:// news.un.org/en/story/2020/04/1061322, accessed in April 2020.
} 
2008/2009. COVID-19 has plunged the world economy into a recession with the potential of deep consequences and historical levels of unemployment and deprivation". ${ }^{96}$ The EU did mobilise a package of over $€ 410$ million in reallocated bilateral financial assistance to support the Western Balkans during the coronavirus emergency and had identified additional $€ 290$ million to help the socio-economic recovery of the whole region ${ }^{97}$. However, this EU approach was overwhelmed by the Chinese quick aid during pandemic, which fuelled comments about widening of Chinese geopolitical influence in the region ${ }^{98}$.

There is also partial responsibility on the Union side. Namely, the region lost a lot of time and enthusiasm in the EU association and also in the accession process, but even after the EU's firm promises of a clear European perspective at the Thessaloniki EUWestern Balkans Summit in 2003, the expectations of most countries in the region were not met. The Stabilization and Association process, set up by the Union as a mechanism for integrating the countries of the region into the EU (Gasmi - Ilic, 2002, p.22), lacked the strength and momentum to accelerate the consolidation of the post-conflict region and assist its essential long-term stabilization. The current tensions in the region prove this assessment. Therefore, the dynamics of the accession process of these countries to the Union remains open. The Union has given the green light to open accession negotiations with Northern Macedonia (a candidate country since December 2005) and with Albania on 25th March 202099, at the same time as the pandemic culminated. The EU is faced with difficulties to define a negotiating platform in absence of common views of its Member States on certain issues (Bulgaria's standpoint on the historical frame of North Macedonia and Greece's caution towards North Macedonia).

Nevertheless, as distant as it may be, the prospect of the EU membership is nonetheless spiritus movens of all the positive changes in the region (Gasmi, 2016, p. 125-126). On the other hand, a high level of economic cooperation is one of the causes of the spillover of the economic crisis from the EU to the Western Balkans. The comparative experience of the previous EU enlargement cycles shows that candidate countries are intensely aligning their markets with the Union's single market (Ceylan, 2006, p. 3). This has led to an additional transfer of the Union's monetary and economic crisis to the economies of the countries of the region.

EU membership may be one, but not the only alternative to the countries that are committed to improving their relations with the Union. There are numerous examples of international trade cooperation models, such as the EEA (European Economic Area), EFTA (European Free Trade Area), etc., which show that other forms of collective cooperation can be equally successful and in no way lack the benefits arising from such forms of cooperation with the EU. With the formation of the Regional Cooperation Council (RCC), composed

\footnotetext{
96 "Shared responsibility, global solidarity: responding to the socio-economic impacts of COVID-19" UN, March 2020, https://unsdg.un.org/sites/default/files/2020-03/SG-Report-Socio-Economic-Impact-of-Covid19. pdf, accessed in April 2020.

${ }^{97}$ https://ec.europa.eu/neighbourhood-enlargement/sites/near/files/coronavirus_support_wb.pdf.

${ }^{98}$ https://foreignpolicy.com/2020/04/08/china-serbia-aleksander-vucic-xi-jinping-coronavirus/.

${ }^{99}$ Launch of membership negotiations with Albania and North Macedonia, 25 March 2020, https://ec.europa. eu/commission/presscorner/detail/en/ip_20_519.
} 
more broadly than the Western Balkans, the countries of the region have already made strides in this direction ${ }^{100}$.

The examples above indicate the possibilities to keep in mind when monitoring the further development of the EU, which will significantly affect its attitude towards the Western Balkan countries, as well as the position of the region towards the Union. The Western Balkan countries, as part of a regional framework represented by structures such as the RCC, may remain in close liaison with the EU as associate members, or continue to pressure the national governments of the EU Member States to accept them as new members.

The region needs stronger co-operation for the joint development of the regional infrastructure, trade, cohesion policy and, in particular, bilateral relations between individual countries of the Western Balkans, which have recently deteriorated significantly. Doing so would highlight the shared common values of the Western Balkans, such as multiculturalism, natural resources, tourism capacities and cohesion. One valuable attempt of enhancing regional cooperation is the initiative of Serbian President A. Vučić to establish so-called Mini - Schengen area in the region, but only North Macedonia and Albania have joined this Serbian initiative through the agreement. The reason for such failure is negative impression in the rest of the region, i.e. that Mini - Schengen was meant to be a substitute for an EU membership. Furthermore, many authors regard the EU conditionality policy towards Serbia in relation to the problem of Kosovo as a huge obstacle to the accessin process, since there are no tangible results of the conditionality approach (Zečević S. $\left.2020^{101}\right)$. EU stability at its southeastern borders can be ensured through its extension to the Western Balkan countries, since the EU's security dimension is incomplete without the Western Balkans region.

The EU requirements for candidate countries have become more complex, more precise and larger in number than the previous twenty-four chapters required a decade ago for the accession of the countries of Central and Eastern Europe. Now there are thirty-one of them, as well as more temporary benchmarks, equilibrium clauses and additional emphasis on political and economic criteria ${ }^{102}$. Some authors particularly criticize the inadequate approach of the $\mathrm{EU}$ in the process of harmonization of the national legal systems of the countries of the region with the Acquis Communautaire, i.e. with EU regulations and

${ }^{100}$ The Regional Cooperation Council (RCC) was officially launched at the meeting of the Ministers of Foreign Affairs of the South-East European Cooperation Process (SEECP) in Sofia, on 27 February 2008, under which auspices it continues to operate. RCC has been working very closely with all the governments in the region and relevant regional cooperation mechanisms. RCC) is an all-inclusive, regionally owned and led cooperation framework. This framework engages RCC participants from the South East Europe (SEE), members of the international community and donors on subjects which are important and of interest to the SEE, with a view to promoting and advancing the European and Euro-Atlantic integration of the region.https://www.rcc.int/ pages/97/participants-from-see.

${ }^{101}$ Zečević S. "Analysis of the Zagreb Declaration - view from Belgrade", expose at the Webinar entitled EU- Western Balkans Summit and the issue of the EU enlargement, held under the auspices of the Hanns Seidel Stiftung in the Institute of European Studies on 19th May 2020,http://www.ies.rs/wpcontent/uploads/2020/05/\%D0\%98\%D0\%95\%D0\%A1-\%D0\%A5\%D0\%A1\%D0\%A1-\%D0\%B2\%D0\% B5\%D0\%B1\%D0\%B8\%D0\%BD\%D0\%B0\%D1\%80-19052020.pdf.

${ }^{102}$ European Commission, Communication on Enhancing the accession process - A credible EU perspective for the Western Balkans, Brussels, 5.2.2020 COM(2020) 57 final. 
policies -being a legal "patchwork" (Mustafaj, 2020, p. 4) in the sense that insufficient account is taken of local legal specifics. The process of harmonization of the national legal systems of the candidate countries constitutes the legal criterion defined in the EU Lisbon Treaty. The accession process is further burdened by the marginalization of this issue on the European Union's agenda due to the actions of the Eurosceptics, but especially because of the pandemic crisis (2020).

There are other challenges for the Western Balkan countries in relation to their future in the EU. Viewed from the Union's perspective, the term "Balkans" refers to the turbulent events of the 1990s, followed by an absence of the rule of law, corruption, organized crime and a failed transition. Although the situation in the region has improved significantly since then, certain aspects of the political and economic situation in the Western Balkans have brought to life these negative stereotypes. The responsibility of the countries of the region themselves for the bad image that survives from the past, lies in the hands of their political elites, who have not wholeheartedly dealt with the traumatic past, nor have they cooperated closely to build common regional interests.

The specificity of the Western Balkans region is contained in its geo-strategic importance for the stability of the Union, despite the challenges and shortcomings outlined above. Therefore, the importance of the region as an essential geopolitical factor for the security and stability of the EU must be reassessed during the accession process of the candidate countries in this area. The comparative advantage of the region lies in its so-called weakness, because it is more constructive and cost-effective for the Union to fully integrate the region into its structures, than to send humanitarian aid and peacekeeping missions (Gasmi-Ilic, 2002, p. 21). Furthermore, from the standpoint of each candidate country, having clearly defined common regional interests in the EU accession process, which are based on solidarity and cohesion, is far more preferable than negotiating solely on their own with a much stronger Union.

The EU has restated its marriage proposal to Western Balkan aspirants, while quietly warning them of Chinese and Russian influence. It is more of an issue of the EU identity than real political competition, since both Russia and China are not against the EU accession of the region. „The EU once again reaffirms its unequivocal support for the European perspective of the Western Balkans," the bloc's 27 leaders said in what they called the "Zagreb Declaration", after meeting their six Balkan counterparts in a video-summit on 6th May $2020^{103}$. However, this Declaration does not mention the enlargement of the EU, which was interpreted in the region as a dissapointing EU approach, despite the EU financial aid of $€ 3.3$ billion aimed at economic recovery of the region. There is a prevailing perception in the Western Balkans region that the Union does not provide sufficient and concrete support for these candidate countries on their path to the EU, compared with the EU's generous approach towards candidate countries of Central and Eastern Europe during their accession stages. This view is also a consequence of mismanagement of expectations in the region with regard to the $\mathrm{EU}$, which does not take into account the internal agony that the Union has been in for a long time (Gasmi, 2016, p. 287), as discussed above.

${ }^{103}$ https://euobserver.com/, accessed on $10^{\text {th }}$ May 2020. 


\section{CONCLUDING REMARKS}

It is important to point out that the current geopolitical context in Europe is reluctant to further enlarge the EU. Most people in the EU Member States highlighted the migrant crisis, security issues, the rise of ultra-right ideologies and movements, the instability of the Eurozone and the complicated EU bureaucratic procedures as responsible. There are views that these problems could be exacerbated if new countries join the internal structures of the EU. The global pandemic adds enormously to the particularly gloomy tone to these challenges.

Jean Monnet wrote in his memoirs that "Europe will move forward in crises, and will be the sum of the solutions adopted for those crises". What is certain is that national support for the EU accession will be diminished in proportion to the absence of the Union's assistance to the candidate countries in the Western Balkans in the longer term on their path to the EU and in the process of their socio-economic recovery from the pandemic. The EU package of a post-pandemic economic support of $€ 3.3$ billion for the region is relatively small compared with the aid to the Member States.

Candidate countries are not only hostages to the current EU institutional weaknesses and a lack of solidarity among the EU Member States, especially during the pandemic, but generally view the Union as a distant target without an adequate policy in the continuing urgent migrant crisis and pandemic. In order to avoid prolonging this situation, it is necessary for each country in the Western Balkans region to focus on the benefits of possible EU membership. In this context, it is useful to highlight the positive aspects of EU candidate countries' membership, in particular: stability in Europe, multiculturalism and diversity, high potentials of tourism and other economic sectors and development of natural resources. This is necessary to dispel negative stereotypes about the Western Balkan countries, but also dilemmas on the part of the Union questioning the need to expand it in order to preserve its own stability and prosperity.

It remains to be seen in the upcoming period whether "Europe-Fortress" is on the scene, with semi-open doors to candidate countries from the Western Balkans region, or is it Europe without borders, with welcome signals to its future members. It would be recommendable and in mutual interest to see the EU's "open doors" for countries of the Western Balkans. 


\section{LIST OF REFERENCES}

Bertelsmann Stiftung, 2015. What Do the People Want? Opinions, Moods and Preferences of European Citizens, Gütersloh, Germany: Bertelsmann Stiftung. https://www.bertelsmannstiftung.de/fileadmin/files/user_upload/Study_EZ_EUpinions_2015.pdf(15th December 2018).

Brehon, N. J. 2020.The European Union and the Coronavirus, Paris. Robert Schuman Foundation. Policy Paper, European issues, $n^{\circ} 553,7^{\text {th }}$ April 2020.http://www.robertschuman.eu (10 $0^{\text {th }}$ April 2020).

Ceylan, O.2006.ACo-integration Analysis Approach to European UnionIntegration:The CaseofAcceding and Candidate Countries, Vienna, European Integration online Papers(EIoP) Vol. 10 (2006) $\mathrm{N}^{\circ} 7$; http://eiop.or.at/eiop/texte/2006-007a.htm (May 2011).

Chopin, T. \&Jamet. J.F. 2016, After the UK's EU referendum: redefining relations between the "two Europe", Paris. Robert Schuman Foundation. Policy Paper, European issues, n³99, 5. 07. 2016, http://www.robert-schuman.eu (September 2016).

Deloy, C, 2016. Supporters and adversaries to the UK remaining in the European Union are running neck and neck in the polls just one month before the referendum, Paris. Robert Schuman Foundation. Policy Paper. http://www.robert-schuman.eu(24. 06. 2016).

Deloy,C.2016. 43 ans après leuradhésion, lesBritanniquesdécident de quitter l'Unioneuropéenne, Paris. Robert Schuman Foundation. Policy Paper. http://www.robert-schuman.eu, (24.06. 2016).

European Policy Centre. 2015. EU member states and enlargement towards the Balkans, Brussels: European Policy Centre.http://aei.pitt.edu/66050/1/pub_5832_eu_member_ states_and_enlargement_towards_the_balkans.pdf (25.01.2016).

Fairhurst, J. 2010.Law of the European Union.England: Longman, Pearson Education L.

Fouéré, E. 2015.The EU's Enlargement Strategy 2015: Will the 'new elements' make a difference? Brussels: CEPS Commentaries. https://www.ceps.eu/system/files/EF\%20 Enlargement\%20Package\%202015.pdf (17. 03. 2016).

Gasmi, G. 2016. Quo Vadis EU? Relevantni pravni i institucionalni faktori. Beograd: Institut za uporedno pravo.

Gasmi, G. \&Zečević, S.2016.Evropskibezbednosniiodbrambeniidentitetimigrantskakriza. Beograd: Institut za uporedno pravo. Strani pravni život.god. 2015, br. 2, p. 57 - 76

Giuliani, J.D. 2020. Now or never,Paris: Foundation Robert Schuman. https://www.jdgiuliani.eu/en/article/cat-2/679_Now-or-Never.html (12.04. 2020).

Ilić - Gasmi, G. 2002. EU Policy towards Western Balkans and the Position of Serbia. Belgrade: GTZ GmBH. 
Ivanda, S. 2001.Schengenski sporazumi i unutarnja sigurnost, Zagreb: Sveučilišna knjiga.

Lopandić, D. \&Janjević, M. 1996. Sporazum iz Šengena - Za Evropu bez granica. Beograd: Međunarodna politika.

Macek L. 2015. Refugee Crisis: A new East - West rift in Europe?Paris: Foundation Robert Schuman. www.robert-schuman.eu (28. 04. 2016).

Matias, B. What the Bulagarian presidency of the Council of the EU meant for the Western Balkans.Sofia: Group for legal and political studies. http://www.legalpoliticalstudies. org/bulgarian-presidency-council-eu-meant-western-balkans (June 20, 2018).

Mustafaj, A.Advocating a true reform of the European Union's enlargement process.Paris: Foundation Robert Schuman. www.robert-schuman.eu(2- 04. 2020).

Piris, J.C. 2010. The Lisbon Treaty - A legal and Political Analysis. Cambridge: Cambridge University Press.

Schulten T. 2014. Contours of a European Minimum Wage Policy Study, Berlin: Friedrich Ebert Stiftung, http://www.fes.de/international/moe (18. 10. 2014).

Regional Cooperation Council, 2013. South-East Europe 2020. Sarajevo: RCC. http://www. rcc.int/files/user/docs/reports/SEE2020-Strategy.pdf (28. 10. 2015).

Sgueo, G. 2015. Lobbying in the EU - the cost of a lack of transparency. Strasbourg: European Parliamentary Research Service. https://www.scribd.com/document/281758925/ Lobbying-in-the- EU-The-cost-of-a-lack-of-transparency (28. 03. 2016).

\section{LEGAL SOURCES}

ECJ Judgement, 2020. Judgment of the General Court in Joined Cases C-715/17, C-718/17 and C-719/17 Commission v Poland, Hungary and the Czech Republic, Court of Justice of the European Union PRESS RELEASE No 40/20 Luxembourg, 2 April 2020, www. curia.europa.eu (15. 04. 2020).

EU Communication 2020. EU, Communication from the Commission to the European Parliament, the Council, the European Economic and Social Committee and the Committee of the Regions: Enhancing the accession process - A credible EU perspective for the Western Balkans, Brussels, 5.2.2020 COM(2020) 57 final,http://ec.europa.eu/ enlargement/pdf (26.04.2020)

EU Communication 2015. EU, Communication from the Commission to the European Parliament, the Council, the European Economic and Social Committee and the Committee of the Regions: EU Enlargement Strategy, Brussels, 10.11.2015, http:// ec.europa.eu/enlargement/pdf/key_documents/2015/20151110_strategy_paper_en.pdf (24.05. 2016). 
EU Regulation 2001. EU, Council regulation (EC) No 539/2001 of 15 March 2001 listing the third countries whose nationals must be in possession of visas when crossing the external borders and those whose nationals are exempt from that requirement", Official Journal of EC, L 81, 21 March 2001: 1-7.

EU Decision 2015. EU, Council Decision (EU) 2015/1601 of 22 September 2015 Establishing provisional measures in the area of international protection for the benefit of Italy and Greece. OJ 2015 L 248, p. 80. (17. 04. 2016.).

EU Enlargement Strategy, 2015. Montenegro 2015 Report, European Commission, SWD (2015) 210 final, Brussels, 10 November 2015, http://ec.europa.eu/enlargement/pdf/ key_documents/2015/20151110_report_montenegro.pdf (29.03.2016).

UN Report, 2020. Shared responsibility, global solidarity: responding to the socio-economic impacts of COVID-19. UN, March 2020, https://unsdg.un.org/sites/default/files/2020-03/ SG-Report-Socio-Economic-Impact-of-Covid19.pdf (10. 04. 2020). 